\title{
PENGARUH PEMASARAN TERHADAP PENJUALAN HASIL TANGKAPAN IKAN PADA PANGKALAN PENDARATAN IKAN (PPI) DESA KRANJI KECAMATAN PACIRAN KABUPATEN LAMONGAN
}

\author{
Faisol Mas'ud dan Aries Premadi
}

Fakultas Perikanan Universitas Islam Lamongan

Jl. Veteran No. 53 A Lamongan

\begin{abstract}
ABSTRAK
Perikanan mempunyai peranan yang sangat penting dalam pembangunan nasional. Hal ini disebabkan karena adanya beberapa faktor. Diantaranya adalah sekitar 2.453.638 orang nelayan dan 1.093.263 rumah tangga budidaya. Menggantungkan hidupnya dari kegiatan usaha perikanan. Adanya sumbangan devisa, yang jumlahnya cukup signifikan dan cenderung meningkat dari tahun ke tahun. Mulai terpenuhnya kebutuhan sumber protein hewani bagi sebagian masyarakat. Terbukanya lapangan kerja bagi angkatan kerja baru, sehingga diharapkan mampu mengurangi angka pengangguran dan adanya potensi perikanan yang dimiliki Indonesia (Dinas Kelautan dan Perikanan, 2006).

Tujuan dari penelitian ini untuk mengetahui pengaruh pemasaran terhadap penjualan hasil tangkapan Ikan pada Pangkalan Pendaratan Ikan (PPI) Kranji di Kecamatan Paciran Kabupaten. Jenis data yang digunakan adalah Data Kualitatif dan Data Kuantitatif. Data Kualitatif yaitu data yang diperoleh dalam bentuk informasi baik secara lisan maupun tulisan yang antara lain berupa sejarah perusahaan dan penjelasan lain dan diperlukan lain dan diperlukan dalam penulisan sedangkan Data Kuantitatif yaitu data yang diperoleh dalam bentuk angka yang dapat dihitung, diperoleh dari perhitungan kuesioner yang akan dilakukan yang berhubungan dengan masalah yang dibahas dalam skripsi ini.

Berdasarkan perhitungan perhitungan analisis dapat disimpulkan bahwa vaiabel pemasaran yaitu produk, harga, promosi dan distribusi secara simultan dan signifikan cukup berpengaruh terhadap variable yaitu Penjualan. Berdasarkan perhitungan, variable citra merek yaitu produk, harga, promosi dan distribusi secara nyata berpengaruh terhadap penjualan ikan pada Pangkalan Pendaratan Ikan (PPI) Kranji Kecamatan Paciran Kabupaten Lamongan dan terlihat variabel harga lebih dominan berpengaruh terhadap penjualan ikan pada Pangkalan Pendaratan Ikan (PPI) Kranji Kecamatan Paciran Kabupaten Lamongan.
\end{abstract}

Keyword : Pangkalan Pendaratan Ikan

\section{PENDAHULUAN}

Negara Indonesia merupakan negara kepulauan yang memiliki sumber daya alam yang melimpah baik yang ada di darat maupun yang ada di laut. Sumberdaya dan tenaga yang dimiliki oleh masyarakat kita maupun modal yang sangat penting dalam mengembangkan usaha-usaha yang ada, terutama usaha di bidang perikanan.

Perikanan mempunyai peranan yang sangat penting dalam pembangunan nasional. Hal ini disebabkan karena adanya beberapa faktor. Diantaranya adalah sekitar 2.453 .638 orang nelayan dan 1.093.263 rumah tangga budidaya. Menggantungkan hidupnya dari kegiatan usaha perikanan. Adanya sumbangan devisa, yang jumlahnya cukup signifikan dan cenderung meningkat dari tahun ke tahun. Mulai terpenuhnya kebutuhan sumber protein hewani bagi sebagian masyarakat. Terbukanya lapangan kerja bagi angkatan kerja baru, sehingga diharapkan mampu mengurangi angka pengangguran dan adanya potensi perikanan yang dimiliki Indonesia (Dinas Kelautan dan Perikanan, 2006).
Dari berbagai penelitian, diperoleh data potensi lestari sumberdaya perikanan laut Indonesia sebesar 6,4 juta ton pertahun. Potensi tersebut berdiri dari ikan pelagis besar sebesar 1,65 juta ton pertahun. Ikan pelagis kecil sebesar 3,6 juta ton, ikan domersal sebesar 1,36 juta ton, ikan karang sebesar 145 ribu ton. Penangkapan yang diperbolehkan adalah 80 persen dari potensi lestari atau sekitar 5,12 juta ton per tahun (Dahuri 2002). Jika mengacu pada pemanfaatan potensi yang diperbolehkan (Total AllowableCatch) tersebut, berarti masih ada sekitar $20 \%$ untuk penambahan produksi hasil tangkapan (Nikujuluw 2002).

Upaya pencapaian pembangunan ekonomi sumber daya perikanan laut ke depan tidak terlepas dari tersedianya sarana dan prasarana yang memadai seperti halnya pangkalan pendaratan ikan tempat berlabuhnya dan bertambahnya kapal untuk melakukan bongkar muat hasil tangkapan ikan atau mengisi bahan pembekalan kegiatan penangkapan ikan. Selanjutnya Lubis (2002) mengemukakan bahwa Pangkalan Pendaratan Ikan ditujukan berlabuhnya perahu-perahu pengangkapan ikan 
tradisional atau perahu-perahu layar tanpa motor.

Pembangunan perikanan mempunyai arti yang sangat penting dan berperang strategis dalam mewujudkan perikanan yang maju dan efisien dan tangguh dalam rangka mendukung transformasi struktur perekonomian nasional. Pembangunan perikanan diarahkan untuk meningkatkan pendapatan dan taraf hidup nelayan, memperluas lapangan kerja dan kesempatan berusaha serta memperluas pasar, baik pasar dalam negeri maupun luar negeri.

Sektor perikanan merupakan salah satu sektor pembangunan yang memiliki peranan yang cukup strategis dalam perekonomian nasional, bahkan sektor ini merupakan salah satu sektor penerimaan devisa negara yang penting. Pembangunan perikanan sebagai bagian dari pembangunan nasional, diarahkan untuk mendukung tercapainya tujuan dan cita-cita luhur bangsa Indonesia dalam mewujudkan masyarakat adil dan makmur. Harapan untuk menjadikan sektor ini sebagai pendukung dalam pencapaian tujuan tersebut didasarkan pada potensi perikanan laut yang dimiliki.

Bidang perikanan merupakan harapan bagi masyarakat untuk meningkatkan pendapatan. Hal ini sejalan dengan arah kebijakan yang mengembangkan system ketahanan pangan yang berbasis pada keragaman sumberdaya bahan pangan ,kelembagaan dan budaya lokal dalam rangka menjamin tersedianya pangan dan nutrisi dalam jumlah dan mutu yang dibutuhkan pada tingkat harga yang terjangkau dalam memperhatikan peningkatan produksi pendapatan petani dan nelayan. Jadi arah kebijakan pembangunan perikanan lebih dibutukan pada peningkatan pendapatan nelayan.

Provinsi Jawa Timur memiliki areal perikanan yang cukup potensial baik perikanan darat dan perikanan laut serta didukung tersedianya sumber daya manusia yang relatif besar. Salah satu daerah di Propinsi Jawa Timur khusus nya di Kbuapten Lamongan yang memilki potensi pengembangan perikanan laut yang cukup besar adalah Tempat Pelelangan Ikan (TPI) Kranji Kecamatan Paciran Kabupaten Lamongan.

Permasalahan dan kendala lain yang masih banyak mempengaruhi kegiatan usaha perikanan di Tempat Pelelangan Ikan (TPI) Kranji Kecamatan Paciran Kabupaten Lamongan adalah menyangkut pengetahuan dan keterampilan nelayan yang masih kurang mengetahui tentang strategi pemasaran sehingga tidak mengetahui harga yang sedang bersaing di pasar internasional untuk komoditas yang ditangkap, serta masalah yang terakhir terbatasnya permodalan. Dalam rangka mengatasi hal tersebut diperlukan pola kemitraan untuk membantu nelayan baik dari segi strategis pemasaran maupun dalam pengetahuan akses penjualan.

Tujuan dari penelian ini untuk mengetahui Pengaruh Pemasaran Terhadap Penjualan Hasil Tangkapan Ikan Pada Pangkalan Pendaratan Ikan (PPI) Kranji di Kecamatan Paciran Kabupaten Lamongan.

\section{Materi dan Metode Penelitian}

Penelitian ini menggunakan data tertulis dengan melakukan observasi langsung dan melakukan wawancara dan mengumpulkan dokumen-dokumen perusahaan yang berhubungan dengan penelitian. Cara tersebut dianggap cukup praktis bagi peneliti untuk melakukan penelitian. Penelitan ini dilakukan di Bulan Mei hingga Juni 2015.

\section{Jenis dan Sumber Data}

Jenis data yang digunakan sebagai berikut :

1. Data Kualitatif

Yaitu data yang diperoleh dalam bentuk informasi baik secara lisan maupun tulisan yang antara lain berupa sejarah perusahaan dan penjelasan lain dan diperlukan lain dan diperlukan dalam penulisan

2. Data Kuantitatif

Yaitu data yang diperoleh dalam bentuk angka yang dapat dihitung, diperoleh dari perhitungan kuesioner yang akan dilakukan yang berhubungan dengan masalah yang dibahas dalam skripsi ini.

Sumber data yang digunakan sebagai berikut :

\section{Data Primer}

Yaitu data yang diperoleh dengan mengumpulkan langsung dari obyek penelitian, yaitu langsung menyebarkan kuesioner kepada responden terpilih.

2. Data Sekunder

Yaitu data yang berupa informasi tertulis maupun tidak tertulis yang diperoleh dari perusahaan, internet, majalah, koran, dan bukubuku yang berhubungan dengan penelitian ini. 


\section{Teknik Pengumpulan Data}

Adapun metode pengumpulan data dalam penelitian ini adalah sebagai berikut :

1. Wawancara

Komunikasi atau pembicaraan dua arah yang dilakukan oleh peneliti dan responden untuk menggali informasi yang relevan dengan tujuan penelitian.

2. Observasi

Pengamatan secara langsung yang dilakukan oleh penulis terhadap objek penelitian guna memperoleh bahan dan data-data yang diperlukan.

3. Kuesioner

Pengumpulan data dengan menggunakan daftar spertanyaan yang telah dibuat, dalam rangka memperoleh data dalam penelitian dimana kuesioner tersebut diajukan hal-hal yang relevan dan berkaitan dengan tujuan penelitian.

4. Studi Pustaka

Teknik pengumpulan data dengan menggunakan data melalui buku-buku, literatur-literatur, berbagai artikel yang dicari lewat website, majalah, maupun koran yang berkaitan dengan penelitian ini.

\section{Populasi dan Sampel}

Populasi dalam penelitian ini adalah Pegawai, Ponggawa dan Pedagang yang ada di Pangkalan Pendaratan (PPI) Kranji. Metode dalam pengambilan sampel adalah teknik nonprobability sampling dengan cara puposive sampling. Pengambilan sampel dengan metode ini bertujuan untuk mendapatkan sampel yang repsentatif sesuai dengan kriteria yang ditentukan. Kriteria tersebut adalah responden yang banyak mengetahui tentang distribusi ikan di Pangkalan Pendaratan (PPI) Kranji. Beberapa ahli mengemukakan bahwa penelitian dianggap baik jika jumlah sampel minimal 30 orang (Sugiyono,2007 Hal 40). Dikarenakan keterbatasan waktu, tenaga, dan biaya, peneliti 50 responden untuk penelitian ini. Jumlah sampel ditentukan berdasarkan rumus Slovin yang dikutip oleh Zeithaml (2000, Hal 160):

$$
n=\frac{N}{1+n(E)^{2}}
$$

Dimana :

$$
\begin{aligned}
& \mathrm{n}=\text { ukuran sampel } \\
& \mathrm{N}=\text { ukuran populasi } \\
& \mathrm{E}=\text { nilai kritis / persentase kelonggaran }(0,1) \\
& \text { Jadi, }
\end{aligned}
$$

$$
\begin{aligned}
& n=\frac{5000}{1+5000(0,1)^{2}} \\
& n=50 \text { responden }
\end{aligned}
$$

Dari hasil perhitungan tersebut maka di ketahui besar sample yang di perlukan adalah 50 responden.

\section{Instrumen Penelitian}

Instrumen penelitian ini adalah kuesioner. Kuesioner ini dirancang menggunakan skala likert. Pada tiap nomor pertanyaan disediakan lima kotak jawaban, dimana tiap kotak jawaban diberi kategori. Responden diminta memilih salah satu kotak diantara lima kotak jawaban yang disediakan sesuai dengan penelitian dengan membutuhkan tanda $(\sqrt{ })$. Data yang berhasil dikumpulkan dari kuesioner selanjutnya akan diukur dengan bobot hitung 1 sampai 5, dengan kategori.

1. Sampai setuju/sangat bagus/sangat menarik/sangat tertarik/dan lain-lain dengan bobot 5 .

2. Setuju/bagus/menarik/tertarik/dan lain-lain dengan bobot 4 .

3. Biasa dengan bobot 3 .

\section{Pembahasan}

\section{Gambaran Umum Wilayah PPI Kranji}

Pangkalan Pendaratan Ikan Kranji merupakan salah satu pangkalan pendaratan ikan di Kabupaten Lamongan disamping PPI Brondong. Pangkalan Pendaratan Ikan Kranji termasuk dalam Wilayah Kecamatan Paciran Kabupaten Lamongan dengan tipe pelabuhan D dalam klasifikasi Pelabuhan Perikanan.

Pembangunan sarana perikanan adalah merupakan salah satu peningkatan produksi dan efisiensi usaha yang mana bertujuan untuk meningkatkan taraf hidup serta kesejahteraan nelayan. Usaha peningkatan produksi ini perlu ditunjang oleh pembangunan sarana dan prasarana perikanan dengan cara membangun pelabuhan perikanan atau pangkalan pendaratan yang dapat memberikan kemudahan bagi nelayan dalam kegiatan produksi pengolahan serta pemaaran.

Pangkalan Pendaratan ikan Kranji Paciran merupakan salah satu pusat pendaratan ikan di Provinsi Jawa Timur dengan fasilitas - fasilitas yang berfungsi dengan baik dan dapat dijangkau oleh kapal-kapal ikan dari berbgai tempat. Peranan pangkalan pendaratan ikan yang cukup penting dalam peningkatan kegiatan masyarakat nelayan dan peningkatan kegiatan produksi. 
PPI Kranji adalah pusat pendaratan ikan yang merupakan salah satu Unit Pelaksana Teknis Daerah (UPTD) yang bertanggung jawab langsung dengan Dinas Kelautan dan Kelautan Kabupaten Lamongan. PPI Kranji yang berfungsi sebagai tempat berlabuhnya atau bertambatnya perahu/kapal perikanan untuk mendaratkan hasil tangkapannya, serta memuat perbekalan kapal dan awak kapal perikanan serta sebagai basis kegiatan produksi, pemasaran dan pengolahan hasil laut serta tempat pembinaan masyarakat nelayan.

TPI Kranji merupakan terletak di Kecamatan Paciran Kabupaten Lamongan dengan mempunyai batas wilayah adalah sebagai berikut

1. Sebelah Utara berbatasan dengan Laut Jawa

2. Sebelah Selatan berbatasan dengan Kecamatan Solokuro.

3. Sebelah Barat berbatasan dengan Kecamatan Brondong.

4. Sebelah Timur berbatasan dengan Kecamatan Panceng Kabupaten Gresik

Pada tahun 2008, pemerintah pusat melalui Departemen Kelautan dan Perikanan mengeluarkan program Pengembangan Sistem Rantai Dingan (Coold Chine System) di berbagai daerah di Indonesia. Khusus Propinsi Jawa Timur, Pangkalan Pendaratan Ikan (PPI) Kranji Kecamatan Paciran Kabupaten Lamongan mendapat kesempatan sebagai tempat pelakasanaan program pengembangan sistem rantai dingin dan merupakan sarana percontohan sistem rantai dingin (CCS) di Propinsi Jawa Timur.

Tujuan adanya usaha pengembangan Sistem Rantai Dingin dalam wilayah Kabupaten Lamongan adalah :

1. Untuk menekan tingkat kemunduran mutu ikan selama proses distribusi berlangsung

2. Meningkatkan mutu produk perikanan dan penyediaan bahan pangan protein hewani yang bergizi dalam rangka peningkatan kualitas Sumberdaya Manusia

3. Meningkatkan mutu dan jaminan keamanan bahan pangan asal ikan dalam rangka perlindungan konsumen

4. Meningkatkan mutu dan nilai tambah yang memiliki daya saing di pasar global

5. Meningkatkan pendapatan dan kesejahteraan masyarakat perikanan

6. Meningkatkan ekspor/devisa Negara

Karakteristik responden terdiri dari konsumen atau pelanggan yang membeli berbagai ikan di Pangkalan Pendaratan Ikan
(PPI) Kranji, penelitian ini secara garis besarnya meliputi karakteristik responden menurut jenis kelamin, umur, pendidikan terakhir, pekerjaan dan pendapatan responden.

Data-data yang diperoleh kemudian diolah dengan menggunakan tabulasi silang, sehingga diperoleh gambaran secara menyeluruh dan terperinci jumlah total dari setiap item yang diteliti dan disusun menurut aliran baris dan kolom, sehingga akan mudah untuk diinterpretasikan secara kuantitatif.

Dalam pengolahan data kuesioner yang menunjukkan bahwa besarnya populasi sebesar 50 orang, sedangkan yang menjadi sampel dalam penelitian ini adalah 50 sampel, dengan metode penarikan sampel adalah Convenience Sampling, yaitu teknik sampling non probability, di mana penentuan unit-unit sampling berdasarkan subjektivitas peneliti. Responden dipilih karena berada di waktu dan tempat yang tepat.

Dalam kaitannya dengan uraian tersebut di atas maka untuk lebih jelasnya karakteristik responden berdasarkan jenis kelamin, umur,pendidikan, pekerjaan serta pendapatan dapat diuraikan sebagai berikut :

1) Karakteristik responden berdasarkan jenis kelamin

Jenis kelamin responden dalam penelitian ini digunakan untuk menentukan tingkat proporsi responden yang berjenis kelamin laki-laki dan wanita. Untuk lebih jelasnya akan disajikan deskripsi profil responden menurut jenis kelamin yaitu sebagai berikut :

Tabel 1.Karakteristik Respoden Berdasarkan Jenis Kelamin

\begin{tabular}{|c|c|c|}
\hline $\begin{array}{c}\text { Jenis } \\
\text { Kelamin }\end{array}$ & $\begin{array}{c}\text { Jumlah } \\
\text { Responden } \\
\text { (Orang) }\end{array}$ & $\begin{array}{c}\text { Persentase } \\
(\%)\end{array}$ \\
\hline Laki-laki & 35 & 76 \\
Perempuan & 15 & 24 \\
\hline Jumlah & 50 & 100 \\
\hline
\end{tabular}

Sumber : Data diolah, tahun 2015

Berdasarkan table diatas yakni deskripsi profil responden yang berdasarkan jenis kelamin, menunjukkan bahwa responden yang berjenis kelamin laki-laki sebesar 35 orang atau $76 \%$ dan yang berjenis kelamin perempuan sebesar 15 orang atau 24\%. Hal ini menunjukkan bahwa mayoritas responden yang merupakan konsumen di Pelelangan Ikan Pangkalan Pendaratan Ikan (PPI) Kranji adalah laki-Laki. 
2) Karakteristik responden berdasarkan Umur

Dalam karakteristik responden berdasarkan umur, menunjukkan bahwa jumlah responden dalam pengambilan sampel ini didasari menurut umur responden yakni antara umur 1625 tahun, 26-35 tahun,36-45 tahun, 46-55 tahun dan lebih dari 55 tahun.

Berdasarkan karakteristik responden menurut umur, dapat disajikan melalui tabel berikut ini :

Table 2 Karakteristik Responden Berdasarkan Umur

\begin{tabular}{|l|c|c|}
\hline \multicolumn{1}{|c|}{ Usia } & $\begin{array}{c}\text { Jumlah } \\
\text { Responden }\end{array}$ & $\begin{array}{c}\text { Presentase } \\
(\%)\end{array}$ \\
\hline 17-25 tahun & 5 & 6 \\
\hline 26-35 tahun & 5 & 6 \\
\hline 36-45 tahun & 7 & 14 \\
\hline 46-55 tahun & 33 & 74 \\
\hline $\begin{array}{l}\text { Lebih dari } 55 \\
\text { tahun }\end{array}$ & - & - \\
\hline \multicolumn{1}{|c|}{ Jumlah } & 50 & 100 \\
\hline
\end{tabular}

Sumber : Diolah tahun 2015

Dari table diatas yakni karakteristik responden pada Pangkalan Pendaratan Ikan (PPI) Kranji di Lamongan yang menunjukkan bahwa dari 50 responden yang dijadikan sampel dalam penelitian ini maka didominasi oleh responden yang berumur antara 46-55 tahun yakni sebesar 33 orang atau $74 \%$, hal ini dapat disimpulkan bahwa sebagian besar konsumen yang membeli ikan di Pangkalan Pendaratan Ikan (PPI) Kranji adalah konsumen yang berumur 46-55 tahun.

3) Karakteristik Responden menurut Pendidikan

Pengelompokan responden berdasarkan pendidikan dapat dilihat melalui tabel berikut ini :

Table 3 Karakteristik Responden Berdasarkan Pendidikan

\begin{tabular}{|c|c|c|}
\hline Pendidikan & $\begin{array}{c}\text { Jumlah } \\
\text { Responden }\end{array}$ & $\begin{array}{c}\text { Presentase } \\
(\%)\end{array}$ \\
\hline SD & 4 & 8 \\
\hline SMP & 18 & 36 \\
\hline SMA & 19 & 38 \\
\hline SARJANA & 9 & 18 \\
\hline Jumlah & 50 & 100 \\
\hline
\end{tabular}

Berdasarkan tabel 4.8.3 yakni karakteristik responden menurut pendidikan, khususnya pada konsumen. Nampak bahwa dari 50 responden yang diteliti, maka didominasi oleh responden yang berpendidikan SMA sebesar 19 orang atau $38 \%$, hal ini berarti bahwa sebagian besar tingkat pendidikan terakhir konsumen yang membeli ikan di Pangkalan Pendaratan Ikan (PPI) Kranji adalah pendidikan SMA.

4) Karakteristik Responden berdarakan pekerjaan Pengelompokan responden berdasarkan pekerjaan dapat dilihat melalui tabel berikut ini

Table 4 Karakteristik Responden Berdasarkan Pekerjaan

\begin{tabular}{|l|c|c|}
\hline Pekerjaan & $\begin{array}{c}\text { Jumlah } \\
\text { Responden } \\
\text { (Orang) }\end{array}$ & $\begin{array}{r}\text { Presentase } \\
(\%)\end{array}$ \\
\hline Pegawai & 25 & 50 \\
\hline Ponggawa & 25 & 30 \\
\hline Pedagang & 10 & 20 \\
\hline Lain-lain & - & - \\
\hline Jumlah & $\mathbf{5 0}$ & $\mathbf{1 0 0}$ \\
\hline
\end{tabular}

Sumber data : Diolah 2015

Tabel 4 menunjukkan bahwa dari 50 orang responden, 25 orang atau $50 \%$ diataranya merupakan pegawai, 15 orang atau $30 \%$ adalah ponggawa dan 10 orang atau $20 \%$ adalah pedagang.

5) Karakteristik berdasarkan pendapatan

Pengelompokkan responden berdasarkan pendapatan dapat dilihat melalui tabel berikut :

Table 5 Karakteristik Responden Berdasarkan Pendapatan

\begin{tabular}{|c|c|c|}
\hline $\begin{array}{c}\text { Tingkat } \\
\text { pendapatan }\end{array}$ & $\begin{array}{c}\text { Jumlah } \\
\text { Respinden } \\
\text { (orang) }\end{array}$ & Persentase (\%) \\
\hline $\begin{array}{c}\text { Dibawah 1 } \\
\text { juta }\end{array}$ & 3 & 6 \\
\hline $\begin{array}{c}2 \text { juta }-5 \\
\text { juta }\end{array}$ & 19 & 38 \\
\hline$>5$ juta & 28 & 56 \\
\hline Jumlah & $\mathbf{5 0}$ & $\mathbf{1 0 0}$ \\
\hline
\end{tabular}

Sumber data : diolah 2015

Berdasarkan tabel 4.8.5 yakni karakteristik responden menurut pendapatan, yang menunjukkan bahwa dari 50 responden yang dikumpulkan, nampak bahwa sebagian besar pendapatan responden adalah diatas Rp. 5 juta yakni sebesar 28 orang atau $56 \%$. Hal ini disimpulkan bahwa sebagian besar pelanggan atau konsumen yang membeli ikan di PPI Kranji adalah mempunyai pendapatan berkisar diata Rp. 5 juta.

\section{Penentuan Range}

Survei ini menggunakan skala Likert dengan bobot tertinggi di tiap pertanyaan adalah 5 dan bobot terendah adalah 1. Dengan jumlah responden sebanyak 50 orang, maka :

Range $=\frac{\text { Skor tertinggi }- \text { Skor Terendah }}{\text { Range Skor }}$ 
Skor tertinggi : $50 \times 5=250$

Skor terendah : 50 × $1=50$

Sehinggan range untuk hasil survei yaitu :

$$
\begin{aligned}
& \quad \frac{250-50}{5}=40 \\
& 50-90=\text { Sangat rendah } \\
& 91-130=\text { Rendah } \\
& 131-170=\text { Cukup } \\
& 171-210=\text { Tinggi } \\
& 211-250=\text { Sangat tinggi }
\end{aligned}
$$

\section{Deskripsi Variabel Bauran Pemasaran dan Perhitungan Skor}

Untuk melihat tanggapan responden terhadap indikator-indikator dan juga perhitungan skor bagi variabel Bauran Pemasaran yang terbagi atas empat yaitu Produk (X1), Price (X2), Promotion (X3), dan Distribution (X4), dapat dilihat berikut ini :

\section{1) Deskripsi Variabel Product (X1)}

Analisis deskripsi jawaban responden tentang variabel Product didasarkan pada jawaban responden atas pernyataan-pernyataan seperti

\begin{tabular}{|c|c|c|c|c|c|c|c|c|c|c|c|}
\hline \multirow{3}{*}{ Pertanyaan } & \multicolumn{10}{|c|}{ Jawaban Responden } & \multirow{3}{*}{ Skor } \\
\hline & \multicolumn{2}{|c|}{ TS } & \multicolumn{2}{|c|}{$\mathrm{KS}$} & \multicolumn{2}{|c|}{ BI } & \multicolumn{2}{|c|}{$\mathrm{S}$} & \multicolumn{2}{|c|}{ SS } & \\
\hline & $\Sigma$ & $\%$ & $\Sigma$ & $\%$ & $\Sigma$ & $\%$ & $\Sigma$ & $\%$ & $\Sigma$ & $\%$ & \\
\hline $\begin{array}{l}\text { Konsumen mudah } \\
\text { menemukan berbagai jenis } \\
\text { ikan }\end{array}$ & - & - & 9 & 18 & 5 & 10 & 30 & 50 & 6 & 12 & 183 \\
\hline $\begin{array}{llll}\text { Banyak stok ikan yang } \\
\text { tersedia }\end{array}$ & - & - & 5 & 10 & 12 & 24 & 28 & 56 & 5 & 10 & 183 \\
\hline $\begin{array}{l}\text { Ikan yang ditawarkan } \\
\text { masih sangat segar }\end{array}$ & - & - & 8 & 16 & 10 & 20 & 22 & 44 & 10 & 20 & 184 \\
\hline
\end{tabular}
yang terdapat dalam kuesioner yang disebarkan pada responden.Variasi jawaban responden untuk variabel product dapat dilihat pada table berikut ini.

Table 6 Tanggapan Responden Terhadap Variabel Produk (X1)

Sumber : Data diolah 2015

Berdasarkan table diatas maka dapat diuraikan beberapa tanggapan responden terhadap variabel Product $(\mathrm{X} 1)$ :

1. Ada indikator pertama yaitu konsumen mudah menemukan berbagai jenis ikan, sebanyak 6 orang atau $12 \%$ menjawab sangat setuju, 30 orang atau $60 \%$ menjawab setuju, 5 orang atau $10 \%$ menjawab biasa, dan 5 orang atau $10 \%$ menjawab kurang setuju.

2. Ada indikator kedua yaitu banyaknya stock ikan yang tersedia, sebanyak 5 orang atau $10 \%$ menjawab sangat setuju, 28 orang atau $56 \%$ menjawab setuju, 12 orang atau $24 \%$ menjawab biasa, dan 5 orang atau $10 \%$ menjawab kurang setuju.
3. ada indikator ketiga yaitu ikan yang ditawarkan masih sangat segar, 10 orang atau $20 \%$ menjawab sangat setuju, 22 orang $44 \%$ menjawab setuju, 10 orang atau $20 \%$ menjawab biasa, dan 8 orang atau $16 \%$ menjawab kurang setuju.

Dari hasil tesebut dapat disimpulkan bahwa tanggapan konsumen terhadap variabel Product pada penjualan ikan di Pangkalan Pendaratan Ikan (PPI) Kranji sebesar 183 berada pada range keempat yaitu tinggi.

\begin{tabular}{|c|c|c|c|c|c|c|c|c|c|c|c|}
\hline \multirow{3}{*}{ Pertanyaan } & \multicolumn{10}{|c|}{ Jawaban Responden } & \multirow{3}{*}{ Skor } \\
\hline & \multicolumn{2}{|c|}{$\mathrm{TS}$} & \multicolumn{2}{|c|}{ KS } & \multicolumn{2}{|c|}{ BI } & \multicolumn{2}{|c|}{$\mathrm{S}$} & \multicolumn{2}{|c|}{ SS } & \\
\hline & $\Sigma$ & $\%$ & $\Sigma$ & $\%$ & $\Sigma$ & $\%$ & $\Sigma$ & $\%$ & $\Sigma$ & $\%$ & \\
\hline $\begin{array}{l}\text { Penetapan harga beli dan harga jual } \\
\text { bersaing }\end{array}$ & & & 12 & 24 & 5 & 10 & 31 & 62 & 2 & 4 & 185 \\
\hline $\begin{array}{l}\text { Harga yang terbilang murah } \\
\text { dibanding harga yang ada di pasar } \\
\text { tradisional }\end{array}$ & 1 & 2 & 6 & 12 & 9 & 18 & 29 & 58 & 5 & 10 & 181 \\
\hline
\end{tabular}

\section{2) Deskripsi Variabel Price (X2)}

Indikator-indikator dari variabel ini terbagi atas tiga yaitu, di mana hasilnya dapat kita lihat sebagai berikut :

Tabel 7 Tanggapan Responden terhadap Variabel Price (X2) 


\begin{tabular}{|l|l|l|l|l|l|l|l|l|l|l|l|}
\hline $\begin{array}{l}\text { Potongan harga terjadi, tergantung } \\
\text { banyaknya ikan yang dibeli oleh } \\
\text { konsumen kepada pemasok }\end{array}$ & & & 7 & 14 & 6 & 12 & 33 & 66 & 4 & 8 & 166 \\
\hline
\end{tabular}

Sumber : Data diolah 2015

Berdasarkan tabel 4.8.7 maka dapat diuraikan beberapa tanggapan responden terhadap variabel Price (X2) :

1. Ada indikator pertama yaitu Penetapan harga beli dan harga jual bersaing, sebanyak 2 orang atau 4\% menjawab sangat setuju, 31 orang atau $62 \%$ menjawab setuju, 5 orang atau $10 \%$ menjawab biasa, dan 12 orang atau $24 \%$ menjawab kurang setuju.

2. ada indikator kedua yaitu harga yang terbilang murah dibanding harga yang ada di pasar tradisional, 5 orang atau $10 \%$ menjawab sangat setuju, 29 orang atau $58 \%$ menjawab setuju, 9 orang atau $185 \%$ menjawa biasa, 6 orang atau $12 \%$ menjawab kurang setuju, dan 1 orang atau $2 \%$ menjawab tidak setuju.

Table 8 Tanggapan Responden terhadap Variabel Promotion (X3)

\begin{tabular}{|c|c|c|c|c|c|c|c|c|c|c|c|}
\hline \multirow{3}{*}{ Pertanyaan } & \multicolumn{10}{|c|}{ Jawaban Responden } & \multirow{3}{*}{ Skor } \\
\hline & \multicolumn{2}{|c|}{ TS } & \multicolumn{2}{|c|}{ KS } & \multicolumn{2}{|c|}{ BI } & \multicolumn{2}{|c|}{$\mathrm{S}$} & \multicolumn{2}{|c|}{ SS } & \\
\hline & $\Sigma$ & $\%$ & $\Sigma$ & $\%$ & $\Sigma$ & $\%$ & $\Sigma$ & $\%$ & $\Sigma$ & $\%$ & \\
\hline $\begin{array}{l}\text { Memberikan informasi } \\
\text { mengenai jenis ikan, harga } \\
\text { yang diperjualbelikan } \\
\text { kepada konsumen }\end{array}$ & 1 & 2 & 2 & 4 & 8 & 16 & 36 & 72 & 3 & 6 & 534 \\
\hline $\begin{array}{ll}\text { Memberikan } & \text { informasi } \\
\text { tentang } & \text { terjadinya } \\
\text { kenaikan harga jika hari } \\
\text { raya atau hari libur }\end{array}$ & & & 1 & 2 & 5 & 10 & 40 & 80 & 4 & 8 & 197 \\
\hline $\begin{array}{lr}\text { Memberikan } & \text { informasi } \\
\text { mengenai } & \text { kurangnya } \\
\text { jumlah hasil tangkapan } \\
\text { ikan disebabkan karena } \\
\text { perubahan musim }\end{array}$ & & & & & 9 & 18 & 38 & 76 & 36 & 6 & 194 \\
\hline
\end{tabular}

Sumber : Data di olah 2015

Berdasarkan tabel diatas maka dapat diuraikan beberapa tanggapan responden terhadap varaibel Promotion (X3) :

1.Ada indikator pertama yaitu memberikan informasi mengenai jenis ikan, harga yang diperjualbelikan kepada konsumen, sebanyak 3 orang atau $6 \%$ menjawab sangat setuju, 36 orang atau $72 \%$ menjawab setuju, 8 orang atau $16 \%$ menjawa biasa, 2 orang atau $4 \%$ menjawab kurang setuju, dan 1 orang atau $25 \%$ menjawab tidak setuju.
3. ada indikator ketiga yaitu potongan harga terjadi, tergantung banyaknya ikan yang dibeli oleh konsumen kepada pemasok, sebanyak 4 orang atau $8 \%$ menjawab sangat setuju, 33 orang atau $66 \%$ menjawab setuju, 6 orang atau $12 \%$ menjawab biasa, dan 7 orang atau $14 \%$ menjawab kurang setuju.

Dari hasil tersebut dapat disimpulkan bahwa tanggapan konsumen terhadap variabel Price sebesar 177 berada pada range keempat yatu tinggi.

3) Deskripsi variabel Promotion (X3)

Indikator - indikator dari variabel ini terbagi atas tiga, di mana hasilnya dapat kita lihat sebagai berikut : 
setuju, 38 orang atau $78 \%$ menjawab setuju, dan 9 orang atau $18 \%$ menjawab biasa.

Dari hasil tersebut dapat disimpulkan bahwa tanggapan konsumen terhadap variabel Promotion sebesar 193 berada pada range kelima yaitu sangat tinggi.

Tabel 9 Tanggapan responden Terhadap Variabel Place (X4)

\begin{tabular}{|c|c|c|c|c|c|c|c|c|c|c|c|}
\hline \multirow{3}{*}{ Pertanyaan } & \multicolumn{10}{|c|}{ Jawaban Responden } & \multirow{3}{*}{ Skor } \\
\hline & \multicolumn{2}{|c|}{$\mathrm{TS}$} & \multicolumn{2}{|c|}{$\mathrm{KS}$} & \multicolumn{2}{|c|}{$\mathrm{BI}$} & \multicolumn{2}{|c|}{$\mathrm{S}$} & \multicolumn{2}{|c|}{ SS } & \\
\hline & $\Sigma$ & $\%$ & $\Sigma$ & $\%$ & $\Sigma$ & $\%$ & $\Sigma$ & $\%$ & $\Sigma$ & $\%$ & \\
\hline Lokasi pasar yang jelas & & & 3 & 6 & 7 & 14 & 31 & 62 & 9 & 18 & 196 \\
\hline $\begin{array}{l}\text { Kenyamanan dan keamanan } \\
\text { pasar saat konsumen berada } \\
\text { di pasar }\end{array}$ & & & 1 & 2 & 13 & 26 & 28 & 56 & 8 & 16 & 193 \\
\hline $\begin{array}{l}\text { Kebersihan tempat (Pasar) } \\
\text { saat menjual berbagai jenis } \\
\text { ikan }\end{array}$ & & & 3 & 6 & 18 & 36 & 25 & 50 & 4 & 8 & 180 \\
\hline Rata-rata & & & & & & & & & & & 190 \\
\hline
\end{tabular}

Sumber : Data diolah 2015

Berdasarkan table 9 maka dapat diuraikan beberapa tanggapan responden variabel Place (X4)

1. Ada indikator pertama yaitu Lokasi pasar yang jelas, sebanyak 9 orang atau $18 \%$ menjawab sangat setuju, 31 orang atau $62 \%$ menjawab setuju, 7 orang atau $14 \%$ menjawab biasa dan 6 orang atau $12 \%$ menjawab kurang setuju.

2. Ada indikator kedua yaitu Kenyamanan dan keamanan pasar saat konsumen berada di Pasar, sebanyak 8 orang atau $16 \%$ menjawab sangat setuju, 28 orang atau $56 \%$ menjawab setujum 13 orang atau $26 \%$ menjawab biasa, dan 1 orang atau $2 \%$ menjawab kurang setuju.

3. Ada indikator ketiga yaitu Kebersihan tempat (Pasar) saat menjual berbagai jenis ikan,
4) Deskripsi variabel berdasarkan Place (X4) Indikator-indikator dari variabel ini terbagi atas tiga yaitu, di mana hasilnya dapat kita lihat sebagai berikut :

Table 10 Tanggapan Responden Untuk Variabel Penjualan

\begin{tabular}{|c|c|c|c|c|c|c|c|c|c|c|c|}
\hline \multirow{3}{*}{ Pertanyaan } & \multicolumn{10}{|c|}{ Jawaban Responden } & \multirow{3}{*}{ Skor } \\
\hline & \multicolumn{2}{|c|}{ TS } & \multicolumn{2}{|c|}{$\mathrm{KS}$} & \multicolumn{2}{|c|}{$\mathrm{BI}$} & \multicolumn{2}{|c|}{$\mathrm{S}$} & \multicolumn{2}{|c|}{ SS } & \\
\hline & $\Sigma$ & $\%$ & $\Sigma$ & $\%$ & $\Sigma$ & $\%$ & $\Sigma$ & $\%$ & $\Sigma$ & $\%$ & \\
\hline $\begin{array}{l}\text { Variabel produk dapat meningkatkan } \\
\text { penjualan berbagai jenis ikan }\end{array}$ & & & 1 & 2 & 9 & 18 & 37 & 74 & 3 & 6 & 192 \\
\hline $\begin{array}{l}\text { Variabel harga dapat meningkatkan } \\
\text { penjualan berbagai jenis ikan }\end{array}$ & & & 2 & 4 & 11 & 22 & 33 & 66 & 4 & 8 & 189 \\
\hline $\begin{array}{l}\text { Variabel promosi dapat meningkatkan } \\
\text { penjualan berbagai jenis ikan }\end{array}$ & & & 3 & 6 & 10 & 20 & 33 & 66 & 4 & 8 & 188 \\
\hline $\begin{array}{l}\text { Variabel distribusi agar dapat } \\
\text { meningkatkan penjualan berbagai jenis } \\
\text { ikan }\end{array}$ & & & 3 & 6 & 9 & 18 & 34 & 64 & 4 & 8 & 185 \\
\hline Rata-rata & & & & & & & & & & & 188 \\
\hline
\end{tabular}

Sumber : Data di olah 2015

sebanyak 4 orang atau $8 \%$ menjawab sangat setuju, 25 orang atau $50 \%$ menjawab setuju, 18 orang atau $36 \%$ menjawab biasa, dan 3 orang atau $6 \%$ menjawab kurang setuju.

Dari hasil tersebut dapat disimpulkan bahwa tanggapan konsumen terhadap variabel Place sebesar 190 berada pada range keempat yaitu tinggi.

\section{Deskripsi Variabel Penjualan dan Perhitungan} Skor

Dalam melakukan kegiatan pemasaran, maka salah satu faktor yang perlu diperhatikan adalah bauran pemasaran karena dalam bauran pemasaran mempengaruhi penjulan, seperti halnya dengan penjualan hasil tangkapan ikan di PPI Kranji, berikut adalah tanggapan responden mengenai penjualan ikan di PPI Kranji. 
Berdasarkan tabel 4.8.10 maka dapat diuraikan jawaban responden menegenai variabel penjualan (Y) :

1. Pertanyaan pertama yaitu variabel produk dapat meningkatkan penjualan berbagai jenis ikan, sebanyak 3 orang atau $6 \%$ menjawab sangat setuju, 37 oarang atau $74 \%$ menjawab setuju, 9 orang atau $18 \%$ menjawab biasa, dan 1 orang atau $2 \%$ menjawab kurang setuju.

2. Pertanyaan kedua yaitu variabel harga dapat meningkatkan penjualan berbagai jenis ikan, sebanyak 4 orang atau $8 \%$ menjawab sangat setuju, 33 orang atau $66 \%$ menjawab setuju, 11 orang atau $22 \%$ menjawab biasa, dan 2 orang atau $4 \%$ menjawab kurang setuju.

3. Pertanyaan ketiga yaitu variabel promosi dapat meningkatkan penjualan berbagai jenis ikan, sebanyak 4 orang atau $8 \%$ menjawab sangat setuju, 33 orang atau 66\% menjawab setuju, 10 orang atau $20 \%$ menjawab biasa, dan 3 orang atau $6 \%$ menjawab kurang setuju.

4. Pertanyaan keempat yaitu variabel distribusi dapat meningkatkan penjualan berbagai jenis ikan, sebanyak 4 orang atau $8 \%$ menjawab sangat setuju, 34 orang atau $68 \%$ menjawab setuju, 9 orang atau $18 \%$ menjawab biasa, dan 3 orang atau $6 \%$ menjawab kurang setuju.

\section{KESIMPULAN}

Berdasarkan perhitungan perhitungan analisis dapat disimpulkan bahwa vaiabel pemasaran yaitu produk, harga, promosi dan distribusi secara simultan dan signifikan cukup berpengaruh terhadap variable yaitu Penjualan.

Berdasarkan perhitungan, variable citra merek yaitu produk, harga, promosi dan distribusi secara nyata berpengaruh terhadap penjualan ikan pada Pangkalan Pendaratan Ikan (PPI) Kranji Kecamatan Paciran Kabupaten Lamongan dan terlihat variabel harga lebih dominan berpengaruh terhadap penjualan ikan pada Pangkalan Pendaratan Ikan (PPI) Kranji Kecamatan Paciran Kabupaten Lamongan.

\section{DAFTAR PUSTAKA}

Alma,Buchari. 2004. Manajemen Pemasaran dan Pemasaran Jasa, cetakan keenam edisi revisi, Bandung : Alfabeta

Alma, Buchari. 2007. Manajemen Pemasaran dan Pemasaran Jasa, Bandung : Alfabeta

Assauri, Sofyan.2008. manajemen Pemasaran,edisi kedua,cetakan kesembilan, Jakarta: Raja
Grafindo persada

Chandra, Gregerius. 2002. Strategi dan Program Pemasaran,edit pertama. Cetakan pertama, Yogyakarta: Andi Offset

Dinas Kelautan, dan Perikanan .2006. laporan dinas kelautan dan perikanan. Makassar

Kotler, Philip. 1995. Principles of Marketing, Analysis, Planning and Control. Terjemahan Herajati Purwoto dan Jaka Wesana, edisi ke dua, Jakarta : Erlangga.

Kotler, Philip. 2000 . Manajemen Pemasaran. Edisi millenium, Jakarta : Prenhallindo.

Kotler, Philip. 2002 . Manajemen Pemasaran, edisi kedua belas, jilid 1 dan II, Jakarta: Erlangga

Kotler, Philip. Dan Kevin, L.K .2007. Manajemen Pemasaran, Terjemahan Benyamin Molan, edisi Kedua Belas Jilid 1, Cetakan Kedua, Jakarta : PT Indeks

Lamb, Charles.W,Joseph F. Hair dan MC Daniel. Pemasaran (Judul asli:Marketing), Edisi Pertama, penerjemah David Octavia,Jakarta : PT Salemba Emban Patria

Marlom H.B Mcdonal. 1999. Marketing Plants that Work, Jakarta: Erlangga

Nikijuluw VPH. 2002. Rezim Pengelolaan Sumber daya perikanan kerjasama $P 3 R$, Jakarta : Pustaka Cidesindo

PPI Paotere. 2008. Laporan Tinjauan Hasil Kegiatan Operasional Makassar

Swastha, B. dan I. Sukotjo . 1995. Pengantar Bisnis Modern, Yogyakarta: Liberty

Winardi. 1989. Srategi Pemasaran (Marketing Strategy), Bandung : Mandar Maju, 